\title{
HAZARD IDENTIFICATION AND PREVENTION METHODS ON WORK IN CONFINED SPACES
}

\author{
Sulardi $^{1}$, Nuruddin Kafy El-Ridho ${ }^{2}$ \\ Sekolah Tinggi Teknologi Minyak dan Gas Bumi (STT Migas) Balikpapan \\ Jln. Sukarno-Hatta KM 8.5, Transad, Karang Joang \\ Email:sulardikm61@yahoo.com ${ }^{1}$; kafyelridlo@gmail.com²
}

\begin{abstract}
The purpose of this study is to provide an overview of potential hazards and safe work procedures in the confined space area of the working of the oil and gas industry. The research method used was the application research method with a case study approach in the oil and gas industry in Balikpapan. The results showed that the potential danger in the room was limited by the danger of lack of oxygen, fire, poisoning explosion, irritation, static electricity, mechanical energy, extreme room temperature, dehydration, insufficient air circulation, slippery surfaces and ergonomic hazards. Safe working procedures in confined spaces were ensuring a safe working environment, use of PPE and work safety equipment, isolation of mechanical equipment, cleaning of gases and liquids, adequate air ventilation and adequate communication systems. The results of the study also recommended supporting the success of work in the confined space area to always be aware of the possibility of toxic gas, low oxygen concentrations and excess, the danger of work equipment and workers equipped with a gas tester.
\end{abstract}

Keywords: Confined Space, Potential Hazards, Oil and Gas Industry.

\begin{abstract}
ABSTRAK
Tujuan penelitian adalah untuk memberikan gambaran potensi bahaya dan prosedur kerja aman di area confined space lingkungan kerja industri minyak dan gas bumi. Metode penelitian yang digunakan adalah metode penelitian aplikasi dengan pendekatan studi kasus di lingkungan industri minyak dan gas bumi di kota Balikpapan. Hasil penelitian menunjukan bahwa potensi bahaya diruang terbatas meliptui bahaya kekurangan oksigen, kebakaran, ledakan, keracunan, iritasi, listrik statis, energy mekanis, suhu ruangan ekstrim, dehidrasi, sirkulasi udara tidak cukup, permukaan licin dan bahaya ergonomis. Prosedur kerja aman di ruang terbatas dengan cara memastikan lingkungan kerja aman, penggunaan APD dan alat keselamatan kerja, isolasi peralatan mekanik, pembersihan gas dan cairan, ventilasi udara yang cukup dan sistim komunikasi cukup. Hasil penelitian juga merekomendasikan untuk mendukung sukses pekerjaan di area confined space agar selalu mewaspadai kemungkinan adanya gas beracun, konsentrasi oksigen yang rendah dan berlebih, bahaya peralatan kerja dan pekerja dibekali dengan gas tester.

Kata kunci: Ruang Terbatas, Potensi Bahaya, Industri Minyak dan Gas.
\end{abstract}




\section{INTRODUCTION}

\section{Background}

Confined space is equipment or work areas that have limitations in access and exit points, is not designed for housing and also contains one or more hazards. Limited space also means space that has a structure such that workers can enter and do work within it, has limited entry and exit paths; there is the potential for chemical, hazardous and toxic gas content. This can result in workers in confined spaces being trapped, experiencing shortness of breath and fainting. Confined space (confined space) or work in confined spaces contains greater potentials for danger than other types of work. The Occupational Safety and Health Service (OSHS), New Zealand, states the potential danger in confined spaces is one hundred fifty (150) times more dangerous than doing the same type of work in another location openly. Equipment and work areas in the confined space category include oil and gas industry equipment such as oil, gas, water and other fluid storage tanks, transport vessels, oil, gas tanks and the like, boilers, heating boilers and the like, sewers, drains dirty and underground wastewater, hoppers, closed tubs, bin and funnel, silos, furnaces, fire heaters, kitchens and other furnaces, piping networks, underground tunnels, airways and underground excavations which are $>1.5$ meters deep there is not enough access road.

\section{The Problems}

The problems in this study are the existence of potential hazards and unsafe conditions when carrying out work in confined spaces. So that testing and efforts are needed to ensure that workplace conditions in confined spaces are conditioned safe and are feasible to work on. The problem of this research is presented in the form of research questions to find answers through this research with research questions (1) what are the potential hazards of working within the confined space area? (2) How does the description of safe working methods work within the confined space area?

\section{The Research Purposes}

The objectives to be achieved with this research activity are to (1) provide an overview of the dangers of working within a confined space area, and (2) provide an overview of safe working methods within a confined space area.

\section{Benefits of Research}

The benefits obtained from the results of this study are (1) a good understanding of work safety issues in the confined space area and methods of handling potential hazards of working in the confined space area, and (2) research output is the publication of research articles in internal/external, and occupational 
safety and health textbooks (OHS) of Oil and Gas Industry.

With the description of the problems above, this research is important to do in order to find answers to research questions and provide solutions to problems experienced in the implementation of work in confined space areas. If this research is not carried out and the potential for danger in the confined space area is unknown and no method of harassment is found then the problem will continue and it is feared that it will result in fatality.

The results of the research Dwi Sandi Bakhtiar and M. Sulaksmono (The Indonesian Journal of Occupational Safety and Health, Vol. 2, No. 1 Jan-Jun 2013: 52-60), showed that in the welding work in confined space areas in the Ship building section of PT. Surabaya Doc and Shipping, the risk control was good enough, accidents that occured due to unsafe behavior of the workers. For this reason, more stringent supervision is needed for implementation of controls in the field. In addition, it is necessary to make Job Safety Analysis on high-risk jobs and be socialized to every worker. Tizi Dzul Khair's research results, 2012 from the University of Indonesia Public Health Study Program showed, in the confined space survey there were five types of permits and the results of risk analysis showed that there were 31 hazards with 21 hazards with an unacceptable level of risk.
The difference between the two studies with the research that researchers do is the focus of the study. This study aims to identify hazards in work in confined spaces and methods of handling them so that confined spaces are safe to do work in. With this there is no similarity in the focus of the two previous studies with the research that researchers do. Thus this research is original, new and has similarities and does not duplicate with previous research.

\section{RESEARCH METHODS}

\section{Equipment Tools}

Equipment tools needed in this research includes air testing and monitoring, air circulation equipment and ventilation systems, communication equipment, lighting equipment, stairs, tripods and fall arrestor, full body harness, equipment for rescue and emergency conditions, gas detector, lamp work, head lamps (gas proof), barriers, ventilation tools, respiratory air suppliers, SCBA, air line respirators and accessories, air quality testing instruments, signal systems (wire systems / hybrid systems, signal ropes) and other safety equipment needed and according to location requirements work.

\section{Personal Protective Equipment (PPE)}

Personal protective equipment (PPE) needed to support work in a confined space 
area consists of safety helmets, gloves, earmuffs/ earplugs, safety belts, goggles/face shields, safety boots, respirators, safety covers and other PPE according to the needs of the job site.

\section{Method and Approachs Research}

The research method used in this study is applied research methods or application research methods in order to overcome the problem (throuble shooting) of potential dangers in the implementation of work in confined spaces. The approach method used in this research is the case study approach method, which is a case study on the work of confined space on fractionation vaccum column equipment, feed charge intake, steam vessel holding, knock out drum, furnace. On the occasion of the turn around the equipment is stopped from operating for cleaning, technical inspection and repair in accordance with the findings of damage to the technical inspection.

\section{Work Methods}

The preparatory phases carried out are (1) ensuring conditions and safety in the work area of limited space before work begins (2) conducting a risk assessment. Risk assessment must be carried out to identify hazards, assess risks, and determine control measures that must be taken, so that all risks that exist in confined spaces can be minimized. All risk assessment results must be well documented (3) making work permits to enter confined spaces that require entry permits. This work permit is very important to ensure the workers involved are indeed competent and understand and follow the safety procedures of working in confined spaces (4) conducting air testing or checking gas content. Atmospheric testing in confined spaces is carried out by competent people to ensure that the atmosphere is free from vapors or toxic and flammable gases and adequate oxygen concentration in the room (5) preparing PPE and supporting equipment needed. All equipment used must consider the possibility of flammable atmosphere, emissions from smoke / gas, electrical risks, and engineering hazards (6) isolating gases, liquids, and other materials. Limited space needs to be isolated from possible entry of material that could endanger workers who are indoors. Insulation includes the closing of pipes or channels, inserting appropriate insulation in the insulated process pipe section, and using two layers of isolation valves (7) isolating mechanical and electrical equipment. Locking and labeling are needed to isolate mechanical and electrical equipment. This aims to prevent work accidents resulting from direct exposure to mechanical and electrical equipment (8) cleaning and discharging gas and liquids in confined spaces. Pressure in the confined space must be reduced and the remaining liquid must be discharged through 
the drain. Clean the gas until it reaches a point below its flammability, then the air may be exhaled using a ventilation system (9) using the required ventilation system. The use of additional ventilation is also needed to ensure an adequate supply of fresh air in confined spaces. Ventilation monitoring must be carried out as long as work is in progress (10) ensuring the necessary communication systems are adequate. Communication systems include talking, hand signals, telephone, radio, or other systems. In essence, make sure communication between workers who are inside with workers who are outside the limited space is established easily, quickly, and clearly.

The problems solving in the confined space area is done by (1) ensuring that the confined space equipment has been steaming out (2) ensuring the confined space equipment has been clustered with warm water and clean water (3) ensuring the confined space equipment has been blended with the wind (4) when no work is done in the confined space area all venting and blowdown remain fully open and the air circulation within the confined space is sufficient (5) at least one person must be outdoors during the activity (6) always comply with safety signs of confined space contained in the work area (7) always check gas content and temperature in confined spaces (8) if workers use breathing apparatus with oxygen supply, always check the condition of the cylinder and its oxygen content (9) ensure that at the time of work all procedures are followed and every worker involved in carrying out their respective responsibilities as well as using recommended personal protection equipment (PPE) and it is stated in the work permit (10) conduct a final inspection to ensure that no equipment and materials are left, all workers have left the confined space, all insulation has been opened and the position is correct, and all permits have been returned and the room has been closed. Indicators and benchmarks of the successful implementation of work and activities in equipment and in the area of confined space have been carried out well, safely and without accidents at work, zero incidents.

\section{RESULTS AND DISCUSSION}

\subsection{Research Result}

Hazards potential contained in work and confined spaces include (1) lack of oxygen (oxygen deficiency $<19.5 \%$ ) or excess oxygen in the air (> 23.5\%) (2) fire or explosion caused by flammable and flammable gases and liquids (3) poisoning liquids, gases and other toxic gas vapors (4) irritation, burns or injuries resulting from direct contact with hazardous and toxic chemicals (5) explosions caused by flammable materials and particles (6) mechanical energy hazards (7) static electricity hazards (8) slippery, slippery and falling surfaces (9) ergonomic hazards due to insufficient space and workplaces (10) tripping, slipping and 
falls (11) extreme room temperature (12) closed / inlet lanes (13) struck down by falling objects / material from above (14) insufficient air circulation (15) workers become dehydrated and exhausted, and (16) other hazards.

The observation results after the equipment is stopped from operation and the venting confined space hole is opened, checking and measuring the gas content with an infrared gas detector sensor and with a gas detector with a catalytic sensor. The findings of testing and checking the condition of hazardous gases in the confined space of the equipment are presented in the following tables.

Table. 1 Result of messurement temperature in internal confined space

\begin{tabular}{|c|c|c|c|c|c|c|c|c|c|}
\hline \multirow[t]{2}{*}{ No } & \multirow[t]{2}{*}{ Peralatan } & \multicolumn{7}{|c|}{ Temperatur $\left({ }^{\circ} \mathrm{C}\right)$} & \multirow{2}{*}{$\begin{array}{l}\text { Standar } \\
\left({ }^{\circ} \mathrm{C}\right)\end{array}$} \\
\hline & & 1 & 2 & 3 & 4 & 5 & 6 & 7 & \\
\hline 1 & Vaccum column & 39 & 37 & 34 & 32 & 29 & 29 & 29 & $18-28$ \\
\hline 2 & Feed charge intake & 37 & 36 & 35 & 33 & 31 & 30 & 30 & $18-28$ \\
\hline 3 & Disengaging drum & 41 & 38 & 36 & 34 & 31 & 29 & 28.5 & $18-28$ \\
\hline 4 & K.0 drum & 37 & 35 & 34 & 31 & 29 & 29 & 28.5 & $18-28$ \\
\hline \multirow[t]{2}{*}{5} & Furnace & 36 & 34 & 33 & 30 & 29 & 29 & 28.5 & $18-28$ \\
\hline & Rata-rata & & & & 32.600 & & & & $18-280^{\circ} \mathrm{C}$ \\
\hline
\end{tabular}

Ref: Kepmenkes RI No.1405/Menkes/SK/XI/2002

The results of examinations and measurements of air conditions in the equipment show that the condition of limited confined spaces is $32.6^{\circ} \mathrm{C}>18-28^{\circ} \mathrm{C}$, in unsafe conditions to enter and requires further treatment to reduce the temperature of the confined space area to a safe limitation.
Table. 2 Result of messurement Oxygin Content in internal confined space

\begin{tabular}{|c|c|c|c|c|c|c|c|c|c|}
\hline \multirow[t]{2}{*}{ No } & \multirow[t]{2}{*}{ Peralatan } & \multicolumn{7}{|c|}{ Kandungan Oksigen (\%) } & \multirow{2}{*}{$\begin{array}{c}\text { Standar } \\
(\%)\end{array}$} \\
\hline & & 1 & 2 & 3 & 4 & 5 & 6 & 7 & \\
\hline 1 & Vaccum column & 17.5 & 18.0 & 18.0 & 18.0 & 18.5 & 18.0 & 18.0 & $19.5-23$ \\
\hline 2 & Feed charge intake & 17.0 & 16.5 & 17.0 & 17.0 & 18.0 & 18.0 & 18.5 & $19.5-23$ \\
\hline 3 & Disengaging drum & 17.5 & 18.0 & 18.0 & 18.0 & 18.0 & 18.5 & 18.0 & $19.5-23$ \\
\hline 4 & K.0 drum & 17.0 & 16.5 & 17.5 & 18.0 & 17.5 & 18.5 & 18.0 & $19.5-23$ \\
\hline 5 & Furnace & 18.0 & 18.0 & 18.5 & 18.5 & 19.0 & 19.0 & 18.5 & $19.5-23$ \\
\hline & Rata-rata & & & & $17.8 \%$ & & & & $19.5-23 \%$ \\
\hline
\end{tabular}

Ref: Kepmenkes RI No.1405/Menkes/SK/XI/2002

Examination results and measurements of oxygen content in the air in the equipment show that the oxygen content in the confined space is on average $17.8 \%<19.5-23 \%$, does not meet the requirements and requires further treatment to increase the oxygen content of the air in the confined space area to the limit secure.

Table. 3 Result of measurement of Sulfuric Acid $\left(\mathrm{H}_{2} \mathrm{~S}\right)$ in internal confined space

\begin{tabular}{|c|c|c|c|c|c|c|c|c|c|}
\hline \multirow[t]{2}{*}{ No } & \multirow[t]{2}{*}{ Peralatan } & \multicolumn{7}{|c|}{ Kandungan Asam Sulfida (ppm) } & \multirow{2}{*}{$\begin{array}{l}\text { Standar } \\
\text { (ppom) }\end{array}$} \\
\hline & & 1 & 2 & 3 & 4 & 5 & 6 & 7 & \\
\hline 1 & Vaccum column & 0 & 0 & 0 & 0 & 0 & 0 & 0 & 0 \\
\hline 2 & Feed charge intake & 0 & 0 & 0 & 0 & 0 & 0 & 0 & 0 \\
\hline 3 & Disengaging drum & 0 & 0 & 0 & 0 & 0 & 0 & 0 & 0 \\
\hline 4 & K.0 drum & 5 & 5 & 3 & 2 & 3 & 2 & 2 & 0 \\
\hline 5 & Furnace & 0 & 0 & 0 & 0 & 0 & 0 & 0 & 0 \\
\hline & Rata-rata & & & & $1 \mathrm{pp}$ & & & & $0 \mathrm{ppm}$ \\
\hline
\end{tabular}

Ref: Kepmenkes RI No.1405/Menkes/SK/XI/2002

Data from measurements of sulfuric acid (H2S) gas content in the confined space show that sulfuric acid (H2S) content mostly meets the requirements and only on internal $\mathrm{KO}$ drums that average sulfide acid content is 3.1 ppm> $0 \%$, unsafe and requires further handling. 
Table. 4 Result of measurement Ammonia

Content in internal confined space

\begin{tabular}{llcccccccc}
\hline No & \multicolumn{1}{c}{ Peralatan } & \multicolumn{9}{c}{ Kandungan Amonia (ppm) } & \multicolumn{1}{c}{ Standar } \\
& & 1 & 2 & 3 & 4 & 5 & 6 & 7 & (ppm) \\
\hline 1 & Vaccum column & 3 & 5 & 3 & 3 & 2 & 2 & 2 & 25 \\
2 & Feed charge intake & 7 & 6 & 3 & 3 & 7 & 7 & 2 & 25 \\
3 & Disengaging drum & 4 & 8 & 3 & 4 & 12 & 9 & 2 & 25 \\
4 & K.0 drum & 14 & 12 & 4 & 14 & 14 & 15 & 12 & 25 \\
5 & Furnace & 12 & 14 & 13 & 13 & 16 & 14 & 16 & 25 \\
\hline \multicolumn{19}{c}{10.3 ppm } \\
\hline
\end{tabular}

Ref : Kepmenkes RI No.1405/Menkes/SK/XI/2002

The results of the examination and measurement of the ammonia (NH3) gas content in the confined space show that the average ammonia (NH3) gas content is 10.3 ppm $<25$ ppm, within safe limits and meets the requirements.

Table. 5 Result of messurement Carbon

Monoxide in confined space

\begin{tabular}{|c|c|c|c|c|c|c|c|c|c|}
\hline \multirow[t]{2}{*}{ No } & \multirow[t]{2}{*}{ Peralatan } & \multicolumn{7}{|c|}{ Kandungan Asam Sulfida (ppm) } & \multirow{2}{*}{$\begin{array}{l}\text { Standar } \\
\text { (ppm) }\end{array}$} \\
\hline & & 1 & 2 & 3 & 4 & 5 & 6 & 7 & \\
\hline 1 & Vaccum column & 5 & 3 & 3 & 3 & 4 & 2 & 4 & 25 \\
\hline 2 & Feed charge intake & 7 & 6 & 3 & 3 & 7 & 7 & 2 & 25 \\
\hline 3 & Disengaging drum & 4 & 8 & 3 & 4 & 12 & 9 & 2 & 25 \\
\hline 4 & K.0 drum & 12 & 10 & 4 & 8 & 6 & 8 & 6 & 25 \\
\hline 5 & Furnace & 10 & 10 & 12 & 6 & 8 & 5 & 7 & 25 \\
\hline & Rata-rata & & & & $9 \mathrm{pp}$ & & & & $25 \mathrm{ppm}$ \\
\hline
\end{tabular}

Ref: Kepmenkes RI No.1405/Menkes/SK/XI/2002

The results of examination and measurement of carbon monoxide (CO) gas content in confined space equipment show that the carbon monoxide $(\mathrm{CO})$ gas content in a confined space is $12 \mathrm{ppm}<25 \mathrm{ppm}$, within safe limits. With the internal confined space condition which is visually still dirty, further handling is needed.

While the results of testing the condition of the contents of the gases in the confined space after cleaning, blowing and circulating air continuously are known, the results are presented in the following table.

Table. 6 Result of measurement temperature In internal confined space

\begin{tabular}{|c|c|c|c|c|c|c|c|c|c|}
\hline \multirow[t]{2}{*}{ No } & \multirow[t]{2}{*}{ Peralatan } & \multicolumn{7}{|c|}{ Temperatur $\left({ }^{\circ} \mathrm{C}\right)$} & \multirow{2}{*}{$\begin{array}{l}\text { Standar } \\
\left({ }^{\circ} \mathrm{C}\right)\end{array}$} \\
\hline & & 1 & 2 & 3 & 4 & 5 & 6 & 7 & \\
\hline 1 & Vaccum column & 26 & 27 & 26 & 25 & 26 & 28 & 27 & $18-28$ \\
\hline 2 & Feed charge intake & 27 & 26 & 25 & 25 & 25 & 26 & 27 & $18-28$ \\
\hline 3 & Disengaging drum & 26 & 25 & 26 & 27 & 26 & 26 & 27 & $18-28$ \\
\hline 4 & K.O drum & 27 & 26 & 26 & 27 & 28 & 26 & 27 & $18-28$ \\
\hline & Furnace & 26 & 28 & 27 & 26 & 26 & 27 & 26 & $18-28$ \\
\hline & Rata-rata & & & & $26,5^{\circ} \mathrm{C}$ & & & & $18-280^{\circ} \mathrm{C}$ \\
\hline
\end{tabular}

Ref: Kepmenkes RI No.1405/Menkes/SK/XI/2002

The results of examinations and measurements of air temperature in the confined space after handling show that the condition of the confined space is an average of $26.5^{\circ} \mathrm{C}$ within the safe limit for work inside.

Table. 7 Result of measurement oxygen content in internal confined space

\begin{tabular}{|c|c|c|c|c|c|c|c|c|c|}
\hline \multirow[t]{2}{*}{ No } & \multirow[t]{2}{*}{ Peralatan } & \multicolumn{7}{|c|}{ Kandungan Oksigen (\%) } & \multirow{2}{*}{$\begin{array}{c}\text { Standar } \\
(\%)\end{array}$} \\
\hline & & 1 & 2 & 3 & 4 & 5 & 6 & 7 & \\
\hline 1 & Vaccum column & 19.5 & 20.5 & 20.0 & 19.5 & 20.0 & 19.5 & 20.5 & $19.5-23$ \\
\hline 2 & Feed charge intake & 19.5 & 20.5 & 20.0 & 20.0 & 20.0 & 20.0 & 20.5 & $19.5-23$ \\
\hline 3 & Disengaging drum & 20.0 & 20.0 & 20.5 & 20.5 & 19.5 & 20.5 & 20.5 & $19.5-23$ \\
\hline 4 & K.0 drum & 19.5 & 20.0 & 19.5 & 20.5 & 19.5 & 20.5 & 20.0 & $19.5-23$ \\
\hline 5 & Furnace & 19.0 & 19.0 & 19.5 & 20.5 & 20.5 & 20.5 & 20.5 & $19.5-23$ \\
\hline & Rata-rata & & & & $20.0 \%$ & & & & $19.5-23 \%$ \\
\hline
\end{tabular}

Ref: Kepmenkes RI No.1405/Menkes/SK/XI/2002

The result of measurements of oxygen content in confined spaces after an average treatment is $20.0 \%$, has met the requirements and is within safe limits for work to be carried out therein. 
Table. 8 Result of measurement sulfuric acid in internal confined space

\begin{tabular}{|c|c|c|c|c|c|c|c|c|c|}
\hline \multirow[t]{2}{*}{ No } & \multirow[t]{2}{*}{ Peralatan } & \multicolumn{7}{|c|}{ Kandungan Asam Sulfida (ppm) } & \multirow{2}{*}{$\begin{array}{l}\text { Standar } \\
\text { (ppom) }\end{array}$} \\
\hline & & 1 & 2 & 3 & 4 & 5 & 6 & 7 & \\
\hline 1 & Vaccum column & 0 & 0 & 0 & 0 & 0 & 0 & 0 & 0 \\
\hline 2 & Feed charge intake & 0 & 0 & 0 & 0 & 0 & 0 & 0 & 0 \\
\hline 3 & Disengaging drum & 0 & 0 & 0 & 0 & 0 & 0 & 0 & 0 \\
\hline 4 & K.O drum & 0 & 0 & 0 & 0 & 0 & 0 & 0 & 0 \\
\hline 5 & Furnace & 0 & 0 & 0 & 0 & 0 & 0 & 0 & 0 \\
\hline & Rata-rata & & & & & & & & Oppm \\
\hline
\end{tabular}

Ref: Kepmenkes RI No.1405/Menkes/SK/XI/2002

The measurement results of sulfuric acid (H2S) gas content in the confined space show that the average sulfuric acid $(\mathrm{H} 2 \mathrm{~S})$ content is $0.0 \mathrm{ppm}$, within the safe limit for work within the confined space area.

Table. 9 Result of messurement Amonia Content in internal confined space

\begin{tabular}{|c|c|c|c|c|c|c|c|c|c|}
\hline \multirow[t]{2}{*}{ No } & \multirow[t]{2}{*}{ Peralatan } & \multicolumn{7}{|c|}{ Kandungan Amonia (ppm) } & \multirow{2}{*}{$\begin{array}{l}\text { Standar } \\
\text { (ppom) }\end{array}$} \\
\hline & & 1 & 2 & 3 & 4 & 5 & 6 & 7 & \\
\hline 1 & Vaccum column & 3 & 5 & 5 & 0 & 0 & 5 & 5 & 25 \\
\hline 2 & Feed charge intake & 6 & 4 & 3 & 3 & 4 & 4 & 2 & 25 \\
\hline 3 & Disengaging drum & 5 & 5 & 0 & 5 & 5 & 5 & 5 & 25 \\
\hline 4 & K.O drum & 5 & 4 & 5 & 4 & 4 & 5 & 3 & 25 \\
\hline 5 & Furnace & 4 & 5 & 3 & 4 & 2 & 5 & 3 & 25 \\
\hline & Rata-rata & & & & & & & & 25 \\
\hline
\end{tabular}

Ref: Kepmenkes RI No.1405/Menkes/SK/XI/2002

The Results of measurement of ammonia gas content (NH3) in the confined space after handling show the ammonia gas content (NH3) in the confined space is $3.0 \mathrm{ppm}<25 \mathrm{ppm}$, within safe limits and has fulfilled the requirements for work inside.
Table. 10 Result of messurement Carbon Moxoide in internal confined space

\begin{tabular}{|c|c|c|c|c|c|c|c|c|c|}
\hline \multirow[t]{2}{*}{ No } & \multirow{2}{*}{ Peralatan } & \multicolumn{7}{|c|}{ Kandungan Asam Sulfida (ppm) } & \multirow{2}{*}{$\begin{array}{l}\text { Standar } \\
(\mathrm{ppm})\end{array}$} \\
\hline & & 1 & 2 & 3 & 4 & 5 & 6 & 7 & \\
\hline 1 & Vaccum column & 5 & 5 & 5 & 5 & 5 & 5 & 5 & 25 \\
\hline 2 & Feed charge intake & 5 & 5 & 5 & 5 & 5 & 3 & 5 & 25 \\
\hline 3 & Disengaging drum & 5 & 4 & 5 & 5 & 3 & 5 & 3 & 25 \\
\hline 4 & K.O drum & 4 & 5 & 5 & 5 & 5 & 4 & 3 & 25 \\
\hline \multirow[t]{2}{*}{5} & Furnace & 3 & 5 & 6 & 5 & 5 & 3 & 2 & 25 \\
\hline & Rata-rata & \multicolumn{7}{|c|}{$4.5 \mathrm{ppm}<$} & $25 \mathrm{ppm}$ \\
\hline
\end{tabular}

Ref: Kepmenkes RI No.1405/Menkes/SK/XI/2002

The results of measurements of carbon monoxide $(\mathrm{CO})$ gas content in the confined space after handling show an average of 4.5 ppm $<25$ ppm, within a safe limit work can be done inside the confined space.

\section{3,2 Discussion}

In order to support the successful implementation of work and activities in confined spaces, action is required in the form of (1) identifying the limited space in the work environment, for that requires an officer who is well trained, and has extensive knowledge about confined spaces to identify limited spaces. (2) be aware of the possibility of toxic gas, namely by being aware of the dangers associated with the atmosphere in confined spaces, one of which can be toxic gas or air containing pollutants at levels that have the potential to endanger humans, for example LEL (Lower Explosive Limit) (3) be aware of the danger of low levels of oxygen concentration, namely by being aware of the level of oxygen concentration when working in confined spaces. The level of oxygen concentration is potentially dangerous if the 
oxygen concentration in the air is less than $19.5 \%$, make sure the level of oxygen concentration is not outside the range $19.5 \%$ $23.5 \%$ of the volume of air (4) be aware of high oxygen concentrations, ie by being aware of the level of oxygen concentration while working at limited room. High levels of oxygen concentration in the air can trigger a fire or explosion. (5) be aware of hazards associated with equipment, that is, be aware of the dangers associated with this. This danger is likely to originate from insulating equipment and improper equipment, for example, portable power tools, mixers or shakers. (6) be aware of the dangers associated with access, i.e. by being aware of the dangers associated with restricted access and entry. The facilities used to enter and exit have the potential danger if the placement or installation is incorrect. (7) ensure that air testing is always carried out, that is by ensuring air testing before limited work in the room is done. The air test must include checking the oxygen content and the flammable and toxic atmosphere. In addition, it is also necessary to assess whether the work carried out will potentially cause changes in limited space conditions. The information obtained will determine the frequency needed to monitor and test the atmosphere in the confined space when the work in on progress.

\section{CONCLUSION}

Potential hazards of working within the confined area have been identified during the preparation of a job safety analysis (JSA) which includes the level of risk and precautionary measures that have been agreed upon and signed by representatives of the relevant departments. The presence of hazardous gas content in confined space equipment has been centralized by steaming out, flushing, compressed air and installing mechanical ventilation with force draft blowers and exhaust venting.

\section{SUGGESTIONS}

Identification of potential hazards of confined space work is mandatory and is written on the job safety analysis sheet. The success of work methods for handling and securing confined space areas and equipment in this study can be replicated to deal with similar problems in other work units.

\section{REFERENCE}

API Standard 560, 2001, Fired Heaters for General Refinery Services, $3^{\text {rd }}$ edition, American Petroleum Institute 1220 L Street, Nortwest Washington, DC. 20005.

API Standard 650, 2013, Welded Tanks for Oil Storage, 13 Edition, American.

David S.J Stan Jones, 2006, Handbook Of Petroleum Processing, Published by Springer, P.O. Box 17, 3300 AA Dordrecht, The Netherlands. 
Keputusan Menteri Kesehatan RI

No.1405/Menkes/SK/XI/2002 tentang

Persyaratan Kesehatan Lingkungan

Kerja Perkantoran dan Industri.

Mohinder L Nayyar, 2000, Piping Handbook,

McGraw Hill Book New York San

Francisco Washington, D.C.

Peraturan Pemerintah Republik Indonesia No.

11 Tahun 1979 tentang Pengolahan dan Pemurnian Minyak Bumi.

Peraturan Menteri Ketenagakerjaan Republik Indonesia No. 37 Tahun 2016 tentang Keselamatan dan Kesehatan Kerja Bejana Tekanan dan Tangki Timbun.

Petroleum Institute Publishing Services, 1220 L Street, NW, Washington, DC 20005.

Reed, Robert D., 1981, Furnace Operations, $3^{\text {rd }}$ edition, Gulf Publishing Company.

Sulardi, 2019, Peralatan Industri Migas, Nusa Litera Inspirasi, Cirebon, Jawa Barat.

Sulardi, 2019, Keselamatan Industri Pengolahan Minyak (K3 Kilang), Nusa Litera Inspirasi, Ceirebon, Jawa Barat.

UU No. 1 Tahun 1970 tentang Keselamatan Kerja.

Wayne B. Geyer, 2000, Handbook Of storage Tank System Codes, Regulation and Design, Marcel Dekker, Inc. All Rights Reserved. 